\title{
Dynamic modelling of nitrous oxide emissions from three Swedish sludge liquor treatment systems
}

Lindblom, E.; Arnell, M.; Flores-Alsina, X.; Stenström, F.; Gustavsson, D. J. I.; Jeppsson, U.

Published in:

Proceedings of the 2014 IWA World Water Congress \& Exhibition

Publication date:

2014

Document Version

Peer reviewed version

Link back to DTU Orbit

Citation (APA):

Lindblom, E., Arnell, M., Flores-Alsina, X., Stenström, F., Gustavsson, D. J. I., \& Jeppsson, U. (2014). Dynamic modelling of nitrous oxide emissions from three Swedish sludge liquor treatment systems. In Proceedings of the 2014 IWA World Water Congress \& Exhibition

\section{General rights}

Copyright and moral rights for the publications made accessible in the public portal are retained by the authors and/or other copyright owners and it is a condition of accessing publications that users recognise and abide by the legal requirements associated with these rights.

- Users may download and print one copy of any publication from the public portal for the purpose of private study or research.

- You may not further distribute the material or use it for any profit-making activity or commercial gain

- You may freely distribute the URL identifying the publication in the public portal 


\section{Dynamic modelling of nitrous oxide emissions from three Swedish full-scale sludge liquor treatment systems}

CONFERENCE PAPER · SEPTEMBER 2014

CITATION

1

6 AUTHORS, INCLUDING:

Magnus Arnell

SP Technical Research Institute of Sweden 10 PUBLICATIONS 13 CITATIONS

SEE PROFILE

Fredrik Stenström

Lund University

2 PUBLICATIONS 2 CITATIONS

SEE PROFILE

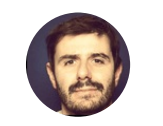

Xavier Flores-Alsina

Technical University of Denmark

50 PUBLICATIONS 383 CITATIONS

SEE PROFILE

Ulf Jeppsson

Lund University

81 PUBLICATIONS 1,578 CITATIONS

SEE PROFILE 


\title{
Dynamic modelling of nitrous oxide emissions from three Swedish full-scale sludge liquor treatment systems
}

\author{
E. Lindblom ${ }^{1,2}$, M. Arnell ${ }^{1,3}$, X. Flores-Alsina ${ }^{4}$, F. Stenström ${ }^{5,6}$, D.J.I. Gustavsson ${ }^{7,8}$, U. Jeppsson ${ }^{1}$ \\ ${ }^{1}$ Div. of Industrial Electrical Engineering and Automation (IEA), Dept of Biomedical Engineering, Lund University, P.O. \\ Box 118, SE-221 00 Lund, Sweden (erik.lindblom@iea.lth.se) \\ ${ }^{2}$ Stockholm Vatten AB, SE-106 36 Stockholm, Sweden (erik.lindblom@ stockholmvatten.se) \\ ${ }^{3}$ Urban Water Management Sweden AB, Gjuterigatan 1D, SE-582 73 Linköping, Sweden \\ ${ }^{4}$ Dept of Chemical and Biochemical Engineering, Technical University of Denmark, Building 229, DK-2800 Lyngby, \\ Denmark \\ ${ }^{5}$ Water and Environmental Engineering, Dept of Chemical Engineering, Lund University, P.O. Box 118, SE-221 00 Lund, \\ Sweden \\ ${ }^{6}$ VA-Ingenjörerna AB, Trädgårdsgatan 12, SE-702 12 Örebro, Sweden \\ ${ }^{7}$ VA SYD, P.O. Box 191, SE-201 21 Malmö, Sweden \\ ${ }^{8}$ Sweden Water Research, Ideon Science Park, Scheelevägen 15, SE-223 70 Lund, Sweden
}

\begin{abstract}
The objective of this paper is to model the dynamics and validate the results of nitrous oxide $\left(\mathrm{N}_{2} \mathrm{O}\right)$ emissions from three Swedish full-scale nitrifying/denitrifying, nitritation and anammox systems treating anaerobic digester sludge liquor. The Activated Sludge Model No. 1 is extended in order to describe $\mathrm{N}_{2} \mathrm{O}$ production by both heterotrophic and autotrophic bacteria. In addition, mass transfer equations are implemented to characterize the dynamics of $\mathrm{N}_{2} \mathrm{O}$ in the water and the gas phases. The biochemical model is simulated for two hydraulic patterns: 1) a sequencing batch reactor (SBR); and, 2) a moving-bed biofilm reactor (MBBR). Preliminary results show that the calibrated model is partly capable of reproducing the behaviour of $\mathrm{N}_{2} \mathrm{O}$ as well as the nitritation/nitrification/denitrification dynamics. However, the results emphasize that more work is required before $\mathrm{N}_{2} \mathrm{O}$ emissions from sludge liquor treatment plants can be generally predicted with certainty by simulations. Continued efforts should focus on determining the switching conditions for different $\mathrm{N}_{2} \mathrm{O}$ formation pathways and, if full-scale data is used, modelling of the measurement devices might improve the conclusions that can be drawn.
\end{abstract}

Keywords: ASMN; Autotrophic denitrification; Greenhouse gases; Heterotrophic denitrification; Modelling; Sludge liquor treatment

\section{Introduction}

Efficient municipal wastewater treatment plant (WWTP) engineering and operation call for plantwide process understanding, which can be summarized as mathematical models. Recent research have shown that some "optimal" WWTP operational strategies, e.g. operation with intermittent aeration and/or low dissolved oxygen (DO) set-points, might be "sub-optimal" in certain respects because of the risk for elevated emission of the undesired greenhouse gas nitrous oxide $\left(\mathrm{N}_{2} \mathrm{O}\right)$. This is possibly due to lack of knowledge and the inability of WWTP simulators to realistically describe this effect. Determining the best actions for mitigation of $\mathrm{N}_{2} \mathrm{O}$ emissions from full-scale WWTP processes is therefore a major problem.

Based on new knowledge of the biological mechanisms of $\mathrm{N}_{2} \mathrm{O}$ production (e.g. Kampschreur et $a l ., 2009$ ), recent efforts have been made to capture the production and emissions of $\mathrm{N}_{2} \mathrm{O}$ and integrate these processes with the traditional ASM models (Hiatt and Grady, 2008; Mampaey et al., 2013; Ni et al., 2013; Pan et al., 2014). The aim is to increase the understanding of the $\mathrm{N}_{2} \mathrm{O}$ production mechanisms and eventually to allow for mitigation and control strategies taking the potential trade-offs between effluent water quality, resource consumption and greenhouse gas production in full-scale plants into consideration and optimize and evaluate such actions by means of simulations.

In this study, a biological process model that includes $\mathrm{N}_{2} \mathrm{O}$ production in processes treating sludge liquors from anaerobic digestion of municipal primary and secondary sludge has been developed, 
implemented and evaluated to test if a combination of the above-mentioned models can be calibrated and validated using the full-scale data.

\section{Material and Methods}

\section{Full-scale data sets}

The model is calibrated to reproduce the data sets from three Swedish full-scale systems denoted $S B R \_N / D N, S B R \_N O 2$ and $M B B R \_A M X$ :

- SBR_N/DN: $\mathrm{N}_{2} \mathrm{O}$ measurements performed by Stenström et al. (2014), who investigated a nitrification(N)-denitrification(DN) SBR process at Slottshagen WWTP (Norrköping, Sweden);

- SBR_NO2: $\mathrm{N}_{2} \mathrm{O}$ measurements performed by Gustavsson and la Cour Jansen (2011), who investigated a nitritation only SBR process at Sjölunda WWTP (Malmö, Sweden); and,

- MBBR_AMX: $\mathrm{N}_{2} \mathrm{O}$ measurements performed by Yang et al. (2013), who investigated a one stage nitritation-anammox moving-bed biofilm reactor process at Hammarby-Sjöstad pilot plant (Stockholm, Sweden).

The three case studies involve anaerobic digestion sludge liquor treatment and all include measurements of traditional wastewater variables (online and grab samples) and online measurements of $\mathrm{N}_{2} \mathrm{O}$ (water and/or gas phase). All measurement results have not been considered in the present study, the reader is referred to the original papers for further details of the experiments.

\section{Mathematical models}

Considering the experimental data of the three case studies, a biological process model including heterotrophic $\left(X_{\mathrm{B}, \mathrm{H}}\right)$ and ammonia oxidizing bacteria $\left(X_{\mathrm{AOB}}\right)$ denitrification was hypothesized to be able to describe the measurements. The model was initially based on the ideas summarized in Hiatt and Grady (2008). This model (ASMN) extends the well-recognized ASM1 (Henze et al., 2000) with two nitrifying populations: $X_{\mathrm{AOB}}$ and nitrite oxidizing bacteria $\left(X_{\mathrm{NOB}}\right)$, using ammonia $\left(S_{\mathrm{NH} 3}\right)$ and nitrous acid $\left(S_{\mathrm{HNO} 2}\right)$, respectively, as substrates. Sequential 4-step heterotrophic denitrification of nitrate $\left(S_{\mathrm{NO} 3}\right)$ to nitrogen gas $\left(\mathrm{N}_{2}\right)$ via nitrite $\left(S_{\mathrm{NO} 2}\right)$, nitric oxide $\left(S_{\mathrm{NO}}\right)$ and $S_{\mathrm{N} 2 \mathrm{O}}$ is also included. However, the ASMN model does not include AOB denitrification, which, as pointed out by Gustavsson and la Cour Jansen (2011) and Stenström et al. (2014) amongst others, potentially is a governing process for $\mathrm{N}_{2} \mathrm{O}$ formation in biological WWTPs. Therefore the $\mathrm{N}_{2} \mathrm{O}$ production mechanisms recently proposed by Mampaey et al. (2013) were included in the model. Thereby, $X_{\mathrm{AOB}}$ are also capable of reducing $S_{\mathrm{HNO} 2}$ to $S_{\mathrm{NO}}$ and further into $S_{\mathrm{N} 2 \mathrm{O}}$. The assumed reaction rates for $X_{\mathrm{AOB}}$ denitrification $\left.\left[\mathrm{g} \mathrm{N} \cdot \mathrm{m}^{-3} \cdot \mathrm{d}^{-1}\right)\right]$ are shown in Eq. 1 and Eq. 2:

$$
\begin{aligned}
& r_{\mathrm{NO}, \mathrm{AOB}, \mathrm{den}}=f_{\mathrm{DNT}, \mathrm{A}} \cdot \frac{\mu_{\mathrm{AOB}}}{Y_{\mathrm{AOB}}} \cdot\left(\frac{S_{\mathrm{O}, \mathrm{AOB}}}{K_{\mathrm{O}, \mathrm{AOB}}+S_{\mathrm{O}, \mathrm{AOB}}}\right) \cdot\left(\frac{S_{\mathrm{NH} 3, \mathrm{AOB}}}{K_{\mathrm{NH} 3, \mathrm{AOB}}+S_{\mathrm{NH} 3}}\right) \cdot\left(\frac{S_{\mathrm{HNO} 2}}{K_{\mathrm{HNO}, \mathrm{AOB}}+S_{\mathrm{NO}}}\right) \\
& r_{\mathrm{N} 2 \mathrm{O}, \mathrm{AOB}, \mathrm{den}}=\frac{\mu_{\mathrm{AOB}}}{Y_{\mathrm{AOB}}} \cdot\left(\frac{S_{\mathrm{O}, \mathrm{AOB}}}{K_{\mathrm{O}, \mathrm{AOB}}+S_{\mathrm{O}, \mathrm{AOB}}}\right) \cdot\left(\frac{S_{\mathrm{NH} 3, \mathrm{AOB}}}{K_{\mathrm{NH} 3, \mathrm{AOB}}+S_{\mathrm{NH} 3}}\right) \cdot\left(\frac{S_{\mathrm{NO}}}{K_{\mathrm{NO}, \mathrm{AOB}}+S_{\mathrm{NO}}}\right)
\end{aligned}
$$

In the original model, the same half-saturation coefficients $K_{\mathrm{O}, \mathrm{AOB}}$ and $K_{\mathrm{NH} \text {,АOB }}$ were assumed for $X_{\mathrm{AOB}}$ aerobic ammonia oxidation and $X_{\mathrm{AOB}}$ denitrification. The parameters $K_{\mathrm{HNO} 2, \mathrm{AOB}}$ and $K_{\mathrm{NO}, \mathrm{AOB}}$ are unique for $X_{\mathrm{AOB}}$ denitrification. Finally, growth and decay processes of anammox active biomass ( $\left.X_{\mathrm{AMX}}\right)$ following Hao et al. (2002) were included in the biological process model. $X_{\mathrm{Amx}}$ convert $S_{\mathrm{NH} 4}$ and $S_{\mathrm{NO} 2}$ to mainly nitrogen gas and also $S_{\mathrm{NO} 3}$ in the absence of oxygen.

Stripping (mass transfer) equations for the gases were implemented as in Foley et al. (2011). In the three case studies, the monitored dissolved oxygen (DO) concentration is used as the input to a 
controller that adjusts the $k_{\mathrm{L}} a_{\mathrm{O} 2}$ of the modelled system. The applied diffusivities of $\mathrm{N}_{2} \mathrm{O}$ and $\mathrm{O}_{2}$ are $1.77 \cdot 10^{-9} \mathrm{~m}^{2} / \mathrm{s}$ and $2.12 \cdot 10^{-9} \mathrm{~m}^{2} / \mathrm{s}$, respectively, yielding $k_{\mathrm{L}} a_{\mathrm{N} 2 \mathrm{O}}=0.91 \cdot k_{\mathrm{L}} a_{\mathrm{O} 2}$. The simulated flux of $\mathrm{N}_{2} \mathrm{O}$ in the offgas $\left(F_{\mathrm{N} 2 \mathrm{O}}\left[\mathrm{kg} \mathrm{N} \cdot \mathrm{d}^{-1}\right]\right)$, which is used to validate the model behaviour with the measured emissions, is then given by $F_{\mathrm{N} 2 \mathrm{O}}=k_{\mathrm{L}} a_{\mathrm{N} 2 \mathrm{O}} \cdot S_{\mathrm{N} 2 \mathrm{O}} \cdot V_{\mathrm{AER}}$, with $V_{\mathrm{AER}}\left[\mathrm{m}^{3}\right]$ denoting the aerated water volume. The simulated $k_{\mathrm{L}} a_{\mathrm{O} 2}$ values are within the range of 300 to $600 \mathrm{~d}^{-1}$. Thus, the half-life of possibly accumulated $S_{\mathrm{N} 2 \mathrm{O}}$ during stripping is only a few minutes. Any long-term dynamic changes should therefore be due to variations of the biological reaction rates. However, the stripping/flux equation might represent an overly simplified version of reality. For example, the retention time of the bubbles in the reactor, the measurement devices and stripping during non-aerated conditions have not been taken into account.

The reactive settler model developed within the BSM framework (Flores-Alsina et al., 2012) was expanded with variable layer heights (e.g. during filling) and layer mixing (e.g. during aeration) to describe the SBR behaviour of $S B R \_N / D N$ and $S B R \_N O 2$ systems.

The biofilm model, used to model the MBBR anammox system (MBBR_AMX), was inspired by the implementation in the commercial software platform WEST 3.7.3 (DHI, 2011). According to this model, the bulk water volume is separated from the biofilm, which in turn is divided into 10 layers. Soluble components are transported by diffusion between the biofilm layers and bulk, proportionally to the concentration gradients. Particulate material attaches to the outermost layer of the biofilm and detachment occurs from all layers as the biofilm thickness exceeds a user defined maximum value.

\section{Results and Discussion}

\section{Nitrification/denitrification sequencing batch reactor, case SBR_N/DN}

Recorded DO and pH values (Fig. 1A \& D) as well as flow rate data were directly used as model inputs. The process temperature was constant $\left(30.3^{\circ} \mathrm{C}\right)$.

During the measurement period of 16 hours used for model calibration the $\mathrm{NH}_{4}{ }^{+}-\mathrm{N}$ load to the SBR plant was $180 \mathrm{~kg} \mathrm{~N} \cdot \mathrm{d}^{-1}$. The SBR_N/DN cycle of 8 hours starts with 3.5 hours of anoxic denitrification including 2 hours of filling. Initially, the accumulation rate of $S_{\mathrm{N} 2 \mathrm{O}}$ is almost equal to the denitrification rate of $S_{\mathrm{NO} 3}$ indicating that the final step of heterotrophic denitrification is inhibited (Fig. 1G). At $\mathrm{t}=1.5 \mathrm{~h}$ ethanol is dosed to the process and $S_{\mathrm{N} 2 \mathrm{O}}$ is immediately reduced. To model these observations with ASMN the heterotrophic $\mathrm{N}_{2} \mathrm{O}$ denitrification process without ethanol must be almost completely inhibited. The original ASMN inhibition term for $S_{\mathrm{NO}}$ was replaced by $S_{\mathrm{NO} 2}$ inhibition (Zhou et al., 2008) since no information of $S_{\mathrm{NO}}$ concentrations was available. Despite several attempts this drastic shift between complete and no inhibition because of a low availability of readily biodegradable substrate $\left(S_{\mathrm{S}}\right)$, could not be captured by the original ASMN model and motivated an extension by an additional model component representing ethanol, $S_{\mathrm{S}, \mathrm{EtOH}}\left[\mathrm{g} \mathrm{COD} \cdot \mathrm{m}^{-3}\right.$ ]. This state variable was assumed to affect the process in the same way as $S_{\mathrm{S}}$, with the exception that the half-saturation coefficient $\left(K_{\mathrm{SEtOH}, 5}\right)$ for heterotrophic growth with $\mathrm{N}_{2} \mathrm{O}$ as electron acceptor is set to a low value $\left(1 \mathrm{~g} \mathrm{COD} \cdot \mathrm{m}^{-3}\right)$. For the same process, but with $S_{\mathrm{S}}$ from the influent sludge liquor as substrate, the half-saturation coefficient $\left(K_{\mathrm{S} 5}\right)$ was given a high value $\left(100 \mathrm{~g} \mathrm{COD} \cdot \mathrm{m}^{-3}\right)$ to model the inhibition without external carbon. According to the simulation results, $S_{\mathrm{N} 2 \mathrm{O}}$ starts to accumulate again as ethanol is consumed, a phenomenon that was not measured and indicates that separated growth on internal and added substrates is not necessarily the actual process governing the $S_{\mathrm{N} 2 \mathrm{O}}$ formation. Other concepts for modelling the denitrification process has recently been presented by Pan et al. (2014) and further experimental work and model calibration are required to fully describe the observed behaviour. 

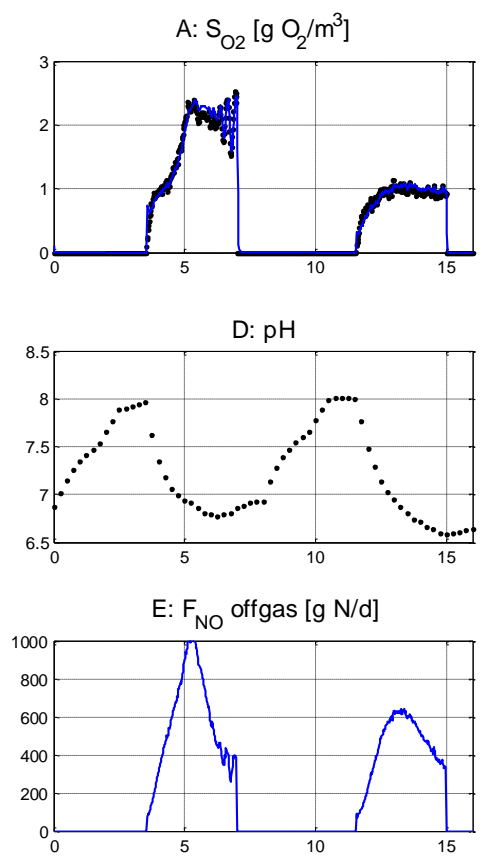

B: ()- $-\mathrm{S}_{\mathrm{NH} 4},\left(^{*}\right)-\mathrm{S}_{\mathrm{NH} 3}{ }^{*} 10\left[\mathrm{~g} \mathrm{~N} / \mathrm{m}^{3}\right]$
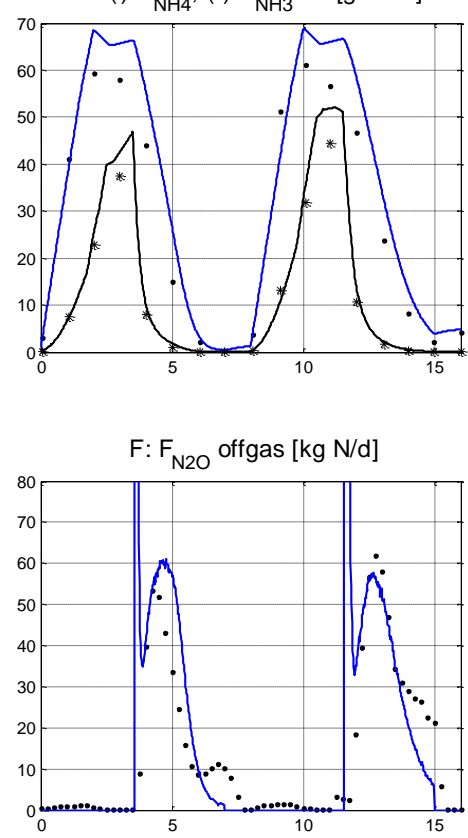
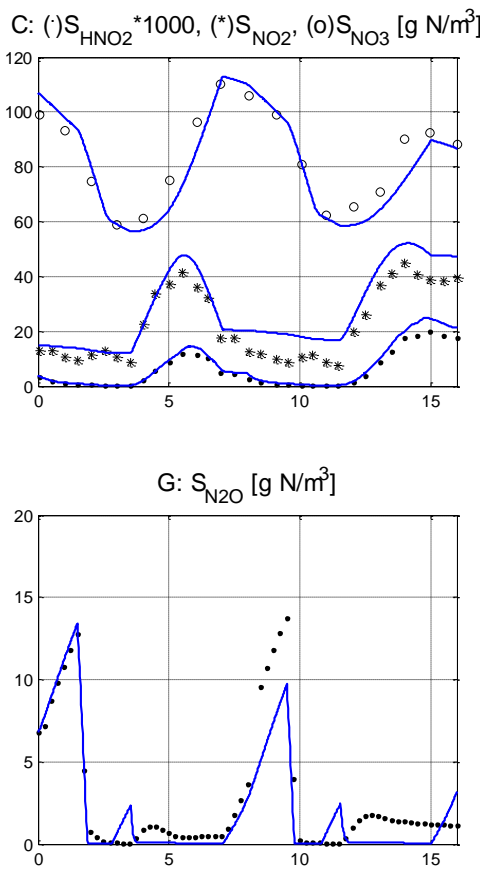

Figure 1. Measured (markers) and simulated (solid lines) concentrations and mass flows for the nitrification/ denitrification SBR process $\left(S B R \_N / D N\right)$. The x-axes show time in hours.

Oxidation of $S_{\mathrm{NH} 3}$ starts instantly when aeration is initiated at $\mathrm{t}=3.5 \mathrm{~h}$ (Fig. 1A \& B). The associated $\mathrm{N}_{2} \mathrm{O}$ emissions are shown in Fig. 1F. A sharp peak in the simulated emission is seen at the start of the aeration due to stripping of the in part faulty prediction of anoxic $\mathrm{N}_{2} \mathrm{O}$ accumulation. The maximum $\mathrm{N}_{2} \mathrm{O}$ emission is reached after 1 hour of aeration although absence of accumulated $S_{\mathrm{N} 2 \mathrm{O}}$ from the preceding anoxic phase. Thus the emission is mainly due to $\mathrm{N}_{2} \mathrm{O}$ production during aerobic conditions. The $X_{\mathrm{AOB}}$ affinity coefficient for $S_{\mathrm{HNO} 2}$ appears relatively low since $S_{\mathrm{HNO} 2}$ peaks after 2.5 hours of aeration (Fig. 1C). As will be shown in the next case study as well, the studied emission seems to be correlated to $S_{\mathrm{NH} 3}$ and in the model this has been accounted for by choosing a separate half-saturation coefficient for $S_{\mathrm{NH} 3}$ during $\mathrm{AOB}$ denitrification, $K_{\mathrm{NH} 3, \mathrm{AOB}, \mathrm{DN}}\left[\mathrm{g} \mathrm{N} \cdot \mathrm{m}^{-3}\right.$ ]. The used value is 7 times higher compared to the value of $K_{\mathrm{NH} 3, \mathrm{AOB}}\left(0.053 \mathrm{~g} \mathrm{~N} \cdot \mathrm{m}^{-3}\right)$ for aerobic ammonia oxidation, see Table 1.

\section{Nitritation only sequencing batch reactor, case SBR NO2}

During the measurement period of 24 hours used for model calibration the $\mathrm{NH}_{4}{ }^{+}-\mathrm{N}$ load to the SBR plant was $710 \mathrm{~kg} \mathrm{~N} \cdot \mathrm{d}^{-1}$. The temperature in the SBR process was similar to $S B R \_N / D N, 31.7^{\circ} \mathrm{C}$. An important difference is, however, that in $S B R \_N O 2$ the $\mathrm{pH}$ was controlled at 6.8. The SBR_NO2 cycle of 6 hours starts with aeration and filling. $S_{\mathrm{NH} 4}$ increases until filling stops after 1.5 hours (Fig. 2B). During the subsequent aerobic batch mode phases, the nitritation process proceeds until aeration is switched off. A fixed constant airflow is applied during each cycle but the total length of the aerated phases is varied. This also means that the time periods for the anoxic settling phases that make up the end of each cycle vary.

The SBR process had been operated for nitritation only during several months prior to this case study and the activated sludge was therefore enriched with $X_{\mathrm{AOB}}$. From the DO data (Fig. 2A) it is seen that the oxygen demand of the sludge decreases when $S_{\mathrm{NH} 4}$ decreases below $50 \mathrm{~g} \mathrm{~N} \cdot \mathrm{m}^{-3}$, which was modelled by a high half-saturation coefficient $\left(K_{\mathrm{NH} 3, \mathrm{AOB}}\right)$ value of $1.1 \mathrm{~g} \mathrm{~N} \cdot \mathrm{m}^{-3}$.

The $\mathrm{N}_{2} \mathrm{O}$ emissions reach $30-75 \mathrm{~kg} \mathrm{~N} \cdot \mathrm{d}^{-1}$ and decrease to $10-15 \mathrm{~kg} \mathrm{~N} \cdot \mathrm{d}^{-1}$ at the end of the aerobic phases (Fig. 2E). In the most extreme cycle (\#4, $\mathrm{t}=18-24 \mathrm{~h}$ ), the emission at the end of the aerated phase is only $20 \%$ of the maximum emission during that same phase. The sharp simulated peaks at the beginning of each phase (not reflected in the measurement data) are due to stripping of accumulated $S_{\mathrm{N} 2 \mathrm{O}}$. Consequently, as stripping according to the model occurs fast, the decrease in 
$\mathrm{N}_{2} \mathrm{O}$ production throughout the aeration phase must be explained by aerobic biological $\mathrm{N}_{2} \mathrm{O}$ production, which is entirely determined by $X_{\mathrm{AOB}}$ denitrification of $S_{\mathrm{NO}}$.
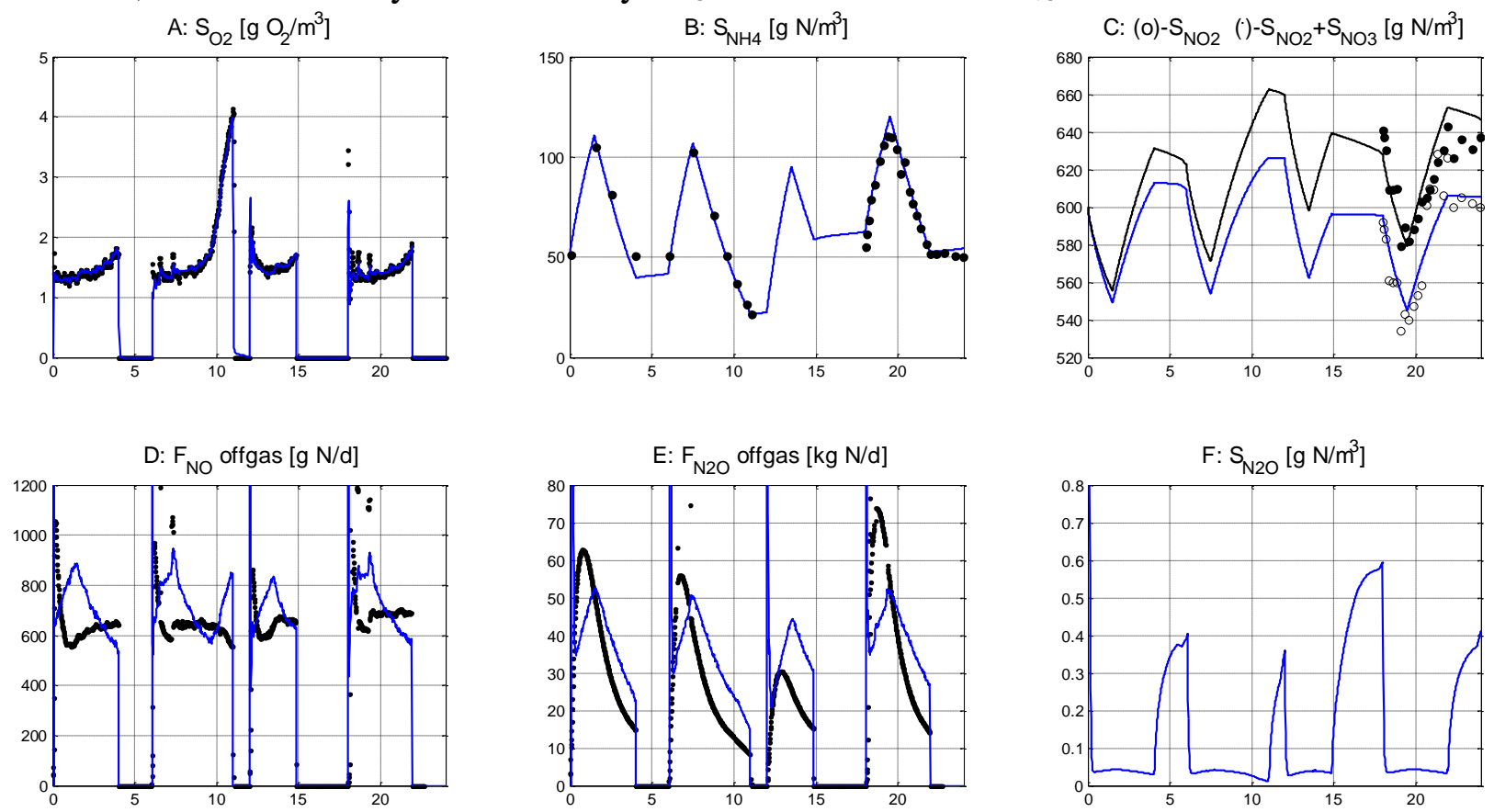

Figure 2. Measured (markers) and simulated (solid lines) concentrations and mass flows for the nitritation only SBR process $\left(S B R \_N O 2\right)$. The $\mathrm{x}$-axes show time in hours.

Opposite to the $S B R \_N / D N$ case this study includes measurements of NO offgas concentrations, which were relatively stable. This is reflected by the almost constant calculated NO emissions shown in Fig. 2D. Considering Eq. 2, $S_{\mathrm{NO}}$ does therefore not explain the dynamic $\mathrm{N}_{2} \mathrm{O}$ emissions. $S_{\mathrm{NO} 2}$ in the process varies around $500-600 \mathrm{~g} \mathrm{~N} \cdot \mathrm{m}^{-3}$ during the nitritation phase (Fig. 2C) and since the concentrations are high they are believed not to represent any major cause for the varying $\mathrm{N}_{2} \mathrm{O}$ emissions. $S_{\mathrm{O}}$ actually increases throughout the aeration phase, a phenomenon that according to the model could increase the $\mathrm{N}_{2} \mathrm{O}$ production (in contrast to the observations).

The attempt to fit the Mampaey model (Mampaey et al., 2013) to the measurement data is not successful and requires the inclusion of - as was also done for $S B R \_N / D N-$ a unique $S_{\mathrm{NH} 3}$ halfsaturation coefficient for AOB denitrification $\left(K_{\mathrm{NH} 3, \mathrm{AOB}, \mathrm{DN}}\right)$. By choosing a high value $\left(7 \mathrm{~g} \mathrm{~N} \cdot \mathrm{m}^{-3}\right)$ the $S_{\mathrm{NH} 3}$ dependency changes towards a linear relation and part of the dynamics can be modelled.

In the original paper describing the experimental data (Gustavsson and Jansen, 2011), a linear relation between the length of the anoxic phase and emitted mass of $\mathrm{N}_{2} \mathrm{O}$ was proposed. The implemented model can be adjusted to explain this phenomenon as seen in the varying peak $S_{\mathrm{N} 2 \mathrm{O}}$ concentrations before aeration (Fig. 2F). However, as already noted, the sharp peaks in the simulated emissions due to stripping were not experimentally supported.

The overall conclusion based on the reasoning above, and several attempts of simulating the model with various parameter sets, is that the ASMN/Mampaey model may not be feasible for explaining the complete dynamics of nitrous oxide emissions from SBR_NO2.

\section{MBBR Anammox, case (MBBR_AMX)}

The influent sludge liquor originated from the full-scale anaerobic digestion process at Bromma WWTP in Stockholm, Sweden. During the measurement period of 24 hours used for model calibration the ammonia load to the pilot-scale reactor was $70 \mathrm{~g} \mathrm{~N} \cdot \mathrm{d}^{-1}$ or $1.7 \mathrm{~g} \mathrm{~N} \cdot\left(\mathrm{m}^{2} \cdot \mathrm{d}\right)^{-1}$. This load corresponds to, compared to other periods, a low load and the amount of biomass in the system should therefore not have limited the total $\mathrm{N}$ removal efficiency $(88 \%)$. The $\mathrm{pH}$ and temperature were relatively constant at 7.1 and $25^{\circ} \mathrm{C}$, respectively. 
The simulated amounts of biomass in the bulk and biofilm are shown in Fig. 3A. $X_{\text {AMx }}$ dominates and is present throughout the entire biofilm. The process is intermittently aerated 45 out of 60 minutes (Fig. 3D) and $X_{\mathrm{AMX}}$ therefore has the possibility to grow also in the outer layers. $X_{\mathrm{AOB}}$ and a small amount of $X_{\mathrm{NOB}}$ are also present in the outer layers. Note that a not insignificant amount of biomass is found in the bulk water volume (shown as dots in Fig. 3A). In the model, and according to experimental observations, there is heterotrophic activity in the system as well.

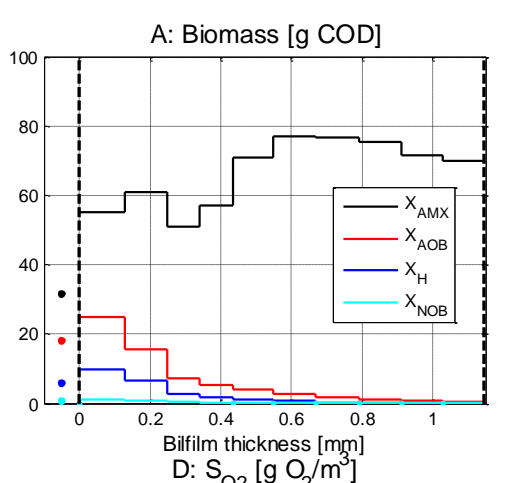

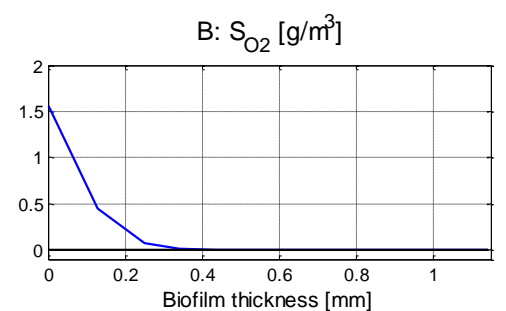

$\mathrm{E}: \mathrm{S}_{\mathrm{NO} 2}\left[\mathrm{~g} / \mathrm{m}^{3}\right]$

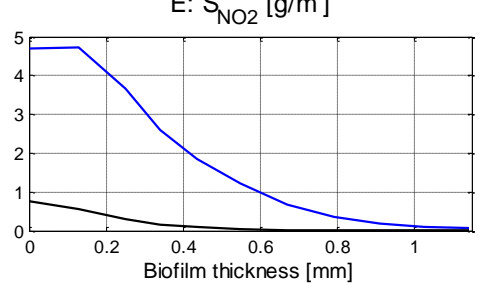

$\mathrm{G}: \mathrm{S}_{\mathrm{N} 2 \mathrm{O}}\left[\mathrm{g} / \mathrm{m}^{3}\right]$

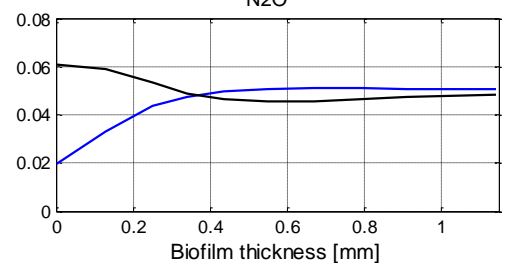

C: $\mathrm{S}_{\mathrm{N} 2 \mathrm{O}}\left[\mathrm{g} \mathrm{N} / \mathrm{m}^{3}\right]$

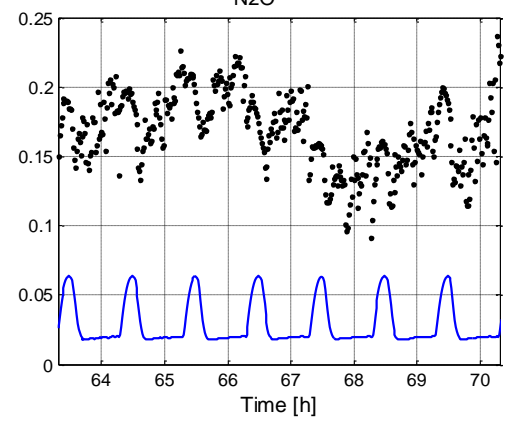

$\mathrm{H}: \mathrm{F}_{\mathrm{N} 2 \mathrm{O}}[\mathrm{g} \mathrm{N} / \mathrm{d}]$

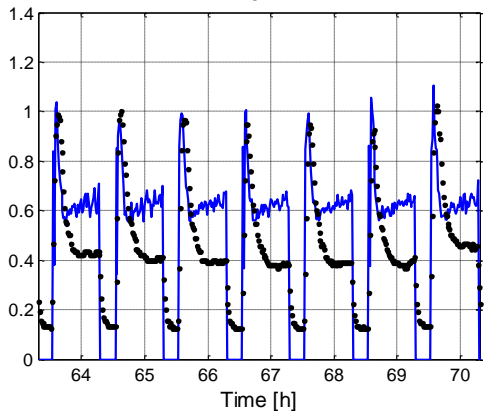

Figure 3. Scenario $M B B R \_A M X$. A: Simulated amounts of active biomass in the biofilm (lines) and bulk (dots). B, E, G: Simulated concentration profiles during the end of aerobic (blue line) and anoxic (black line) conditions. C, D, F, H: Measured (markers) and simulated (solid lines) concentrations and mass flows.

Simulation results show that, compared to the previous case studies, the relatively low $\mathrm{N}_{2} \mathrm{O}$ emissions of $0.5 \%$ during the studied period can be explained by heterotrophic denitrification. In the demonstrated simulations (Fig. 3) the ASMN default parameters for $X_{\mathrm{B}, \mathrm{H}}$ were used. Approximately $3 \%$ of the influent $S_{\mathrm{NH} 4}$ is converted via nitrification and heterotrophic denitrification and $20 \%$ out of this amount is accumulated as $S_{\mathrm{N} 2 \mathrm{O}}$, probably because of low $S_{\mathrm{S}}$ concentrations from hydrolysis of particulates in the biofilm. The resulting emissions of $\mathrm{N}_{2} \mathrm{O}$ are similar to the measurements and therefore, to simplify, AOB denitrification is not considered. It should be noticed that higher emission rates of $\mathrm{N}_{2} \mathrm{O}$ were measured during other periods of the measurement campaign, which might indicate AOB denitrification. The reader is referred to Yang et al. (2013) for further information.

Fig. $3 \mathrm{~F}$ shows the simulated and measured bulk $S_{\mathrm{NH} 4}$ concentrations. $S_{\mathrm{NO} 3}$ varied between 60 and $65 \mathrm{~g} \mathrm{~N} \cdot \mathrm{m}^{-3}$ and both $S_{\mathrm{NH} 4}$ and $S_{\mathrm{NO} 3}$ fully penetrate the modelled biofilm. Fig. $3 \mathrm{~B}, \mathbf{E} \boldsymbol{\&} \mathbf{G}$ show simulated concentration profiles from the bulk water through the biofilm layers at two occasions. The black line shows the profile after 15 minutes of anoxic conditions in the bulk while the blue line shows concentrations after 45 minutes of aeration. From these results it can be seen that $S_{\mathrm{NO} 2}$ (Fig. 3E) is produced in the outer layer during aerobic conditions and penetrates almost the entire biofilm. When aeration is turned off, $S_{\mathrm{N} 2 \mathrm{O}}$ is consumed by $X_{\mathrm{AMX}}$ and $X_{\mathrm{B}, \mathrm{H}}$. During anoxic conditions, $S_{\mathrm{N} 2 \mathrm{O}}$ diffuses into the biofilm where it is converted by heterotrophic denitrifiers. As aeration is turned on $S_{\mathrm{N} 2 \mathrm{O}}$ in the bulk volume decreases due to stripping and the diffusion changes direction so that $S_{\mathrm{N} 2 \mathrm{O}}$ moves from the biofilm to the bulk. 
The simulated $\mathrm{N}_{2} \mathrm{O}$ emissions are shown in Fig. 3H. Emissions were measured also during nonaerated phases, which were not considered in the model. The simulated and measured dissolved $\mathrm{N}_{2} \mathrm{O}$ concentrations are shown as time-series in Fig. 3C. The measurement data do not show a clear pattern but occasionally it can be seen that $S_{\mathrm{N} 2 \mathrm{O}}$ increase during anoxic conditions.

The simulated $S_{\mathrm{N} 2 \mathrm{O}}$ concentrations are generally lower than the measured ones. Based on the implemented model it is difficult to calibrate this effect because $F_{\mathrm{N} 2 \mathrm{O}}$ (which is quite well predicted) is proportional to $S_{\mathrm{N} 2 \mathrm{O}}$ and $k_{\mathrm{L}} a_{\mathrm{N} 2 \mathrm{O}}$. Thus, if the measurements are correct, either the stripping/flux model (including the diffusion coefficients) or the estimated $k_{\mathrm{L}} a_{\mathrm{O} 2}$ is wrong.

\section{Applied parameter values}

In Table 1 below, a summary of the parameter values for $X_{\mathrm{H}}$ and $X_{\mathrm{AOB}}$ are shown. The table is not complete but includes the values that differ from the original publications (Hiatt and Grady, 2008; Mampaey et al., 2013) and show the major differences between the three case studies.

Table 1. Calibrated model parameter values for the three case studies.

\begin{tabular}{|c|c|c|c|c|c|c|c|c|c|}
\hline \multirow{4}{*}{$\begin{array}{l}S B R \_N / D N \\
S B R \_N O 2 \\
M B B R \_A M X\end{array}$} & \multicolumn{3}{|c|}{$\left[\mathrm{g} \mathrm{COD} \cdot \mathrm{m}^{-3}\right]$} & \multirow{2}{*}{$\begin{array}{c}\begin{array}{c}K_{\mathrm{I} 5, \mathrm{HNO} 2} \\
{\left[\mathrm{~g} \mathrm{~N}^{-3} \mathrm{~m}^{-3}\right]}\end{array} \\
0.001\end{array}$} & & & & & \\
\hline & 20 & 100 & 1 & & & & & & \\
\hline & 20 & 40 & - & - & & & & & \\
\hline & 20 & 40 & - & - & & & & & \\
\hline & $b_{\mathrm{AOB}}$ & $\begin{array}{l}\mu_{\mathrm{AOB}} \\
]\end{array}$ & $\begin{array}{c}f_{\mathrm{DNT}, \mathrm{A}} \\
{[-]}\end{array}$ & $\begin{array}{c}Y_{\mathrm{AOB}} \\
{\left[\mathrm{g} \mathrm{COD}^{-1}\right.} \\
\left(\mathrm{g} \mathrm{N}^{-1}\right]\end{array}$ & $\begin{array}{c}K_{\mathrm{O}, \mathrm{AOB}} \\
{\left[\mathrm{g} \mathrm{O}_{2} \cdot\right.} \\
\left.\mathrm{m}^{-3}\right]\end{array}$ & $K_{\mathrm{NH} 3, \mathrm{AOB}}$ & $\begin{array}{r}K_{\mathrm{NH} 3, \mathrm{AOB}, \mathrm{DN}} \\
{[\mathrm{g} \mathrm{N}}\end{array}$ & $\begin{array}{l}K_{\mathrm{HNO} 2, \mathrm{AOB}} \\
\left.1^{-3}\right]\end{array}$ & $K_{\mathrm{NO}, \mathrm{AOB}}$ \\
\hline$S B R \_N / D N$ & 0.23 & 2.00 & 0.12 & 0.18 & 1.0 & 0.053 & 0.368 & 0.003 & 0.06 \\
\hline$S B R \_N O 2$ & 0.23 & 2.00 & 0.05 & 0.18 & 1.0 & 1.100 & 7.000 & 0.001 & 0.06 \\
\hline$M B B R \_A M X$ & 0.08 & 1.41 & - & 0.18 & 1.0 & 0.053 & - & - & - \\
\hline
\end{tabular}

\section{Conclusions}

The implemented biological process model, together with physical models for the SBR- and MBBRprocess can partly describe the $\mathrm{N}_{2} \mathrm{O}$ emission data from the three case studies.

The AOB denitrification model, which was adopted from Mampaey et al. (2013), could be fitted quite well to explain the behaviour of the nitrifying/denitrifying SBR. For the nitritation only SBR a high correlation to the ammonia concentration had to be assumed and may indicate that the implemented model is not able to fully describe the dynamics of the real system.

The four-step denitrification model, which was adopted from Hiatt and Grady (2008), could be used to model accumulation of dissolved $\mathrm{N}_{2} \mathrm{O}$ during anoxic conditions in the nitrifying/denitrifying $\mathrm{SBR}$. To model $\mathrm{N}_{2} \mathrm{O}$ emission reduction caused by addition of ethanol, an additional COD state variable had to be added.

The stripping/flux equation in the implemented model may be overly simplified. It results in sharp $\mathrm{N}_{2} \mathrm{O}$ gas emission peaks that are not observed experimentally. For simulation of full-scale $\mathrm{N}_{2} \mathrm{O}$ emission data in general, the retention time of the gas including the measurement devices could probably improve the conclusions that can be drawn regarding $\mathrm{N}_{2} \mathrm{O}$ formation pathways.

The $\mathrm{N}_{2} \mathrm{O}$ emissions from the studied MBBR anammox process data where satisfactorily simulated by assuming heterotrophic denitrification only. The results from this case are preliminary and other measurements, which have not been considered in the present study, may indicate that AOB denitrification occurs as well. 


\section{Acknowledgements}

Dr Lindblom and Mr Arnell acknowledge the financial support obtained through the Swedish Research Council Formas (contract no. 211-2010-141), the Swedish Water \& Wastewater Association (contracts no. 10-106 and 11-106) and the J. Gust. Richert Memorial Fund (contract no. PIAH/11:58). Dr Flores-Alsina gratefully acknowledges the financial support provided by the People Program (Marie Curie Actions) of the European Union's Seventh Framework Programme FP7/2007-2013 under REA agreement 329349.

\section{References}

DHI (2011). WEST: modelling wastewater treatment plants - user guide. DHI, Hørsholm, Denmark.

Flores-Alsina, X., Gernaey, K.V. and Jeppsson, U. (2012). Benchmarking biological nutrient removal in wastewater treatment plants: influence of mathematical model assumptions. Water Sci. Technol., 65(8), 1496-1505.

Foley J., Yuan Z., Keller J., Senante E., Chandran K., Willis J., van Loosdrecht M.C.M. and van Voorthuizen E. (2011). $\mathrm{N}_{2} \mathrm{O}$ and $\mathrm{CH}_{4}$ emission from wastewater collection and treatment systems. Technical report, Global Water Research Coalition, London, UK.

Gustavsson D.J.I. and Jansen J. la Cour (2011). Dynamics of nitrogen oxides emission from a full-scale sludge liquor treatment plant with nitritation. Water Sci. Technol., 63(12), 2838-2845.

Hao X.D., Heijnen J.J. and van Loosdrecht M.C.M. (2002). Sensitivity analysis of a biofilm model describing a one-stage completely autotrophic nitrogen removal (CANON) process, Biotechnol. Bioeng., 77, 266-277.

Henze M., Gujer W., Mino T. and van Loosdrecht M.C.M. (2000). Activated Sludge Models ASM1, ASM2, ASM2d and ASM3. IWA Scientific and Technical Report No. 9, IWA Publishing, London, UK.

Hiatt W.C. and Grady Jr. C.P.L. (2008). An updated process model for carbon oxidation, nitrification and denitrification. Water Environ. Res., 80(11), 2145-2156.

Kampschreur M.J., Temmink H., Kleerebezem R., Jetten M.S.M. and van Loosdrecht M.C.M. (2009). Nitrous oxide emission during wastewater treatment. Water Res., 43(17), 4093-4103.

Mampaey K.E., Beuckels B., Kampschreur M.J., Kleerebezem R., van Loosdrecht, M.C.M. and Volcke E.I.P. (2013). Modelling nitrous and nitric oxide emissions by autotrophic ammonia-oxidizing bacteria. Environ. Technol., 34(12), 1555-1566.

Ni B.J., Yuan Z., Chandran K., Vanrolleghem P.A. and Murthy S. (2013). Evaluating four mathematical models for nitrous oxide production by autotrophic ammonia-oxidizing bacteria. Biotechnol. Bioeng., 110(1), 153-163.

Stenström F., Tjus K. and Jansen J. la Cour (2014). Oxygen-induced dynamics of nitrous oxide in water and off-gas during the treatment of digester supernatant. Water Sci. Technol., 69(1), 84-91.

Yang J., Trela J., Plaza E. and Tjus K. (2013). $\mathrm{N}_{2} \mathrm{O}$ emissions from a one stage partial nitrification/anammox process in moving bed biofilm reactors. Water Sci. Technol., 68(1), 144-152.

Zhou Y., Pijuan M., Zeng R.J. and Yuan Z. (2008). Free nitrous acid inhibition on nitrous oxide reduction by a denitrifying-enhanced biological phosphorus removal sludge. Environ. Sci. Technol., 42(22), 8260-8265. 